\title{
Differences in above-ground resource acquisition and niche overlap between a model invader (Phragmites australis) and resident plant species: Measuring the role of fitness and niche differences in the field
}

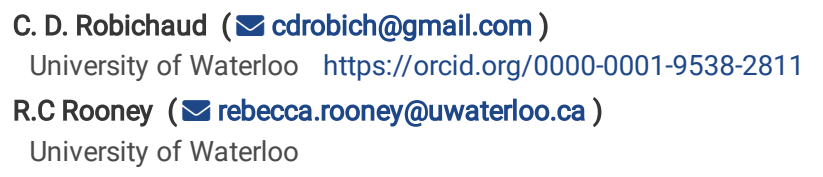




\section{Abstract}

Identifying the mechanisms that result in a "high impact" invasive species can be difficult. Coexistence theory suggests that detrimental invasive species can be better predicted by incorporating both niche differences and fitness differences than examining niche overlap alone. Specifically, detrimental invasive species should take up shared limited resources more efficiently than their neighbouring resident species. While there is clear evidence that invasive Phragmites australis is successfully displacing resident species, there remains few field studies that attempt to quantify the niche overlap and fitness difference between P. australis and the species it is displacing in the field. Using P. australis we measured differences in photosynthetic performance (carbon assimilation rates, $\delta 13 \mathrm{C}$, photosynthetic water use efficiency, biomass), the effects of competition for photosynthetically active radiation, and niche overlap between P. australis and three resident freshwater wetland species ( Calamagrostis canadensis, Carex aquatilis, and Typha spp.) growing with or without interspecific competition . Invasive P. australis intercepted more photosynthetically active radiation, assimilated more carbon more efficiently, and had a larger niche region compared to resident species. Resident plant species showed a significant decrease in photosynthetic performance when growing in competition with P. australis and had a high probability of overlap onto the niche space of P. australis. These results provide evidence that the ability of P. australis to reduce the availability of a required resource and more efficiently use it over the growing season, while exhibiting high niche overlap with resident species, likely contributes directly to its success in North American freshwater wetlands.

\section{Introduction}

Identifying the mechanisms that confer an advantage to an introduced species can be challenging. Work rooted in niche theory suggests that a resident community may have niche space, or untapped resources, that can be exploited by an introduced species (e.g., Elton 1958; Richardson and Pyšek 2006). It is also often posited that a successful invader is a superior competitior compared to its native neighbours, though this advantage can be transient or might works in concert with other environmental variables (Gioria and Osborne 2014). For example, the interactions between environmental and biological components of a system will influence community composition and species establishment (e.g., Kraft et al. 2015), while fluctuations in spatial or temporal niche opportunities (e.g., Chesson and Huntly 1997) can favour the coexistence of seemingly similar species. The complexities of biological communities can make it difficult to predict the effects of invasive species using a unified framework.

Both community assembly (Pearson et al. 2018) and coexistence theory (e.g., Chesson 2000) have provided structures to guide invasion ecology that account for the complexities of biological interactions. In the community assembly framework, invasive species might "break the rules" of the resident community by having rare traits that benefit them relative to community-specific conditions (Pearson et al. 2018). This can include traits that allow them to better take up resources or cope with limited resources (Gioria and Osborne 2014). MacDougall et al. (2009) applied a coexistence theory framework to invasion ecology and proposed that niche differences (or differences that benefit a species when they are rare) and fitness differences (or differences that benefit one species regardless of their rarity in the community), jointly explain how introduced species become established and why they are deleterious to the resident community. Essentially, an introduced species with a large fitness difference and high niche overlap with the resident community is more efficient at drawing down shared resources and therefore more likely to establish and result in negative ecological effects on resident species (MacDougall et al. 2009).

Phragmites australis subsp. australis (European common reed) is a perennial wetland grass originally from Europe that is now found throughout North American wetlands (Saltonstall 2002). Compared to the North American native Phragmites australis subsp. americanus, invasive $P$. australis generates more above-ground biomass, and has a higher specific leaf area and relative growth rate (Mozdzer and Megonigal 2012). Additionally, invasive $P$. australis tolerates a wide range of environmental conditions. These include surviving in water depths ranging from $30 \mathrm{~cm}$ below to $70 \mathrm{~cm}$ above the ground-level (Haslam 1971 ), in salinities ranging from freshwater to salt marshes (e.g., Konisky and Burdick 2004; Vasquez et al. 2005), and in a wide range of soil nutrient concentrations (Packer et al. 2017) - for example, Meyerson et al. (1999) reported $P$. australis growing in soil with a range of $0.35-14.7$ mg g ${ }^{-1}$ nitrogen. Invasive $P$. australis also responds positively to disturbance and nutrient addition by increasing the density and height of above-ground shoots (Minchinton and Bertness 2003) and generates more biomass when grown in elevated $\mathrm{CO}_{2}$ treatments, suggesting it may fare better under climate change (Mozdzer and Megonigal 2012). Due to the extensive amount of research conducted on invasive $P$. australis, it has been formally suggested as a model organism with which to study plant invasions (Meyerson et al. 2016).

Although challenging to work with because of its rhizomatous, perennial life history, invasive $P$. australis is interesting because of its ability to establish itself in highly productive wetland ecosystems where niche space should be scarce (e.g., Macarthur and Levins 1967; Levine and D'Antonio 1999; Keane and Crawley 2002). In saltmarshes (e.g., Chambers et al. 1999) and freshwater marshes (e.g., Wilcox 2012) of North America, invasive $P$. australis has replaced native vegetation communities and reduced plant species richness (Meyerson et al. 2000). The species-rich plant communities located in the coastal marshes of Long Point, a peninsula on the north shore of Lake Erie, are one such system that has been largely converted to invasive $P$. australis (haplotype $\mathrm{M}$ ) in the last few decades (Wilcox et al. 2003). During this period of growth $P$. australis most often replaced emergent marsh, sedge meadows and meadow marsh (Wilcox et al. 2003; Jung et al. 2017). Emergent marsh was typically in deeper water $(>30 \mathrm{~cm}$ ) and dominated by cattail; principally, Typha x glauca (Godr. (pro sp.)), an invasive cattail resulting from hybridization between Typha latifolia (L.) and Typha angustifolia (L.) (Pieper et al. 2020). On the opposite end of the moisture gradient $(<20 \mathrm{~cm})$ was usually meadow marsh dominated by grasses (e.g., Calamagrostis canadensis ((Michx.) P. Beauv.)) and in between lay sedge meadow dominated by Carex spp.; mainly $C$. aquatilis). Remnant patches of these three marsh communities remain in Long Point, but recent work suggests that if water levels remain stable $P$. australis will continue to spread at current rates (14-37\% annually), potentially eliminating these remnants of resident species (Jung et al. 2017).

We hypothesize 1) that $P$. australis more efficiently assimilates carbon than resident species, a fitness difference that contributes to its success in diverse vegetation communities, 2 ) that $P$. australis intercepts more photosynthetically active radiation than resident species, leading to a negative effect of competition for resident species, a niche difference that benefits $P$. australis, and 3 ) that $P$. australis exhibits considerable overlap with the niche space of key resident species that span a range in preferred water depths (C. canadensis, $C$. aquatilis, and Typha spp.) due to its wide range of environmental tolerances. 
While there is clear evidence that $P$. australis is successfully displacing resident plant communities in freshwater marshes, no field studies have quantified niche overlap and fitness differences between $P$. australis and these key resident species. The marshes of Long Point thus provide an opportunity to test these hypotheses and the coexistence framework proposed by MacDougall et al. (2009) with a well-studied and problematic model invasive species (Meyerson et al. 2016). Thereby, we will explain a component of the mechanisms that make $P$. australis such a detrimental invasive species.

\section{Methods}

\section{Study Site}

We conducted our experiment in Long Point Provincial Park, Long Point, Ontario, CA ( $42^{\circ} 35^{\prime} 01^{\prime \prime} \mathrm{N}, 80^{\circ} 22^{\prime} 37^{\prime \prime}$ W; Appendix A). Long Point is a freshwater coastal marsh located on the north shore of Lake Erie and is a designated World Biosphere Reserve, Ramsar Wetland, and a globally significant Important Bird Area. Wetland vegetation in these marshes assemble along a water depth gradient from deep standing water (up to $70 \mathrm{~cm}$ ) to shallow standing water or saturated soils.

This range of water depths is subdivided into three distinctive vegetation communities: emergent marsh (deepest), sedge meadow (intermediate) and meadow marsh (shallowest). Each of these vegetation communities comprises multiple plant species, but evenness is typically low (Robichaud and Rooney 2021), with each community dominated by a characteristic rhizomatous perennial that reproduces sexually and asexually. Coincidentally, these are traits that are shared by $P$. australis. For emergent marsh, the dominant species is most likely Typha $\mathrm{x}$ glauca, but identification based on morphology is difficult in the field due to extensive hybridization (Travis et al. 2010; Bansal et al. 2019) so we instead refer to "Typha spp." throughout. Sedge meadow was most commonly dominated by Carex aquatilis (water sedge [Wahlenb.]) and meadow marsh by Calamagrostis canadensis (Canada bluejoint grass). Hereafter, Typha spp., $C$. aquatilis, and $C$. canadensis are referred to as "resident species." Like $P$. australis, Typha x glauca generates dense monocultures (e.g., Galatowitsch et al. 1999), and C. canadensis is taxonomically closely related to $P$. australis as they both belong to the Poaceae family.

\section{Experimental set up}

For our experiment we selected replicate phytometers (an individual stem/ramet used to measure plant responses to experimental manipulations) of $P$. australis and the three resident species representative of each remnant vegetation community. All phytometers were situated along the leading edge of a $P$. australis stand (Appendix A). This best approximates realistic competition in invaded areas, as $P$. australis relies mostly on clonal expansion once it has established itself through seeds or clonal propagules (Kettenring et al. 2016). To minimize intraspecific competition, we selected resident phytometers that were growing surrounded primarily by $P$. australis within the stand and $P$. australis phytometers that were growing surrounded by each resident species. All of the phytometers were established in the same area, with a maximum distance of $150 \mathrm{~m}$ between plots (Appendix A).

We selected 96 phytometers on 23-May-2016 (Appendix B) and 27-May-2017 (Appendix C), for a total of 192 phytometers. Each year, these included 24 phytometers of Carex aquatilis and 24 of $C$. canadensis. We included only 12 phytometers of Typha spp. each year as these were more robust and less prone to damage during the field season. We included 36 phytometers of $P$. australis (12 each to compare with the three resident species). Phytometer pairs of equivalent height were identified for each species and one member of each pair was assigned at random to the 'with interspecific aboveground competition' treatment while the other was assigned to the 'without interspecific aboveground competition' treatment. This ensured that both treatments included phytometers spanning the full range of early-growing season ramet heights (Appendix D).

To create the 'without interspecific aboveground competition' treatment, we clipped all plants growing in the $1 \mathrm{~m}^{2}$ area surrounding the phytometer to within 2 $\mathrm{cm}$ of the soil. For the 'with interspecific aboveground competition' treatments, we did not alter the surrounding above-ground biomass within $1 \mathrm{~m}^{2}$ around the phytometer. However, to limit potential clonal subsidy and standardize belowground interactions, as all the phytometer species are rhizomatous clonal species, we severed roots and rhizomes in both the 'with competition' and 'without competition' treatments by sawing the perimeter of the 1 m ${ }^{2}$ plots to a depth of $50 \mathrm{~cm}$ with a hand saw. We performed this once, as pilot work determined that severing the below-ground material repeatedly caused physical disturbance detrimental to the phytometers.

Approximately every 10 days, we measured the height of phytometers and re-clipped the surrounding vegetation in the 'without competition' treatment. Over the course of the experiment all phytometers were subject to natural herbivory and physical stresses. Phytometers that were consumed or died are reported in Appendix B \& C.

Once phytometers had matured (in July, but dates varied between years with interannual differences in weather), we measured the carbon assimilation rate $\left(\mu \mathrm{mol} \mathrm{CO} \mathrm{s}^{-1} \mathrm{~m}^{-2}\right)(\mathrm{A})$ and photosynthetic water use efficiency $\left(\mathrm{CO}_{2}\right.$ mmol s$\left.{ }^{-1} \mathrm{~m}^{-2} \mathrm{H}_{2} \mathrm{O}\right)$ (WUE) of each phytometer using a CIRAS-3 true differential gas analyzer with a PLC3 Universal LED Light Unit (RGBW) and PLC3 narrow leaf cuvette (PP Systems, Amesbury, MA, USA). We selected a fresh, entire (e.g., no damage) leaf growing with maximum sun exposure from each phytometer and then measured a photosynthesis-irradiance (PI) curve in the field. The PI curve began by exposing the leaf to $1500 \mu \mathrm{mol} \mathrm{s} \mathrm{m}^{-2}$ of photosynthetically active radiation, equivalent to an average full-sunlight day during the growing season, and slowly reduced PAR to $1000,500,200,100,50$, and $0 \mu \mathrm{mol} \mathrm{s}{ }^{-1} \mathrm{~m}^{-2}$ while simultaneously measuring carbon assimilation and photosynthetic water use efficiency. Measurements at each PAR level were taken until carbon assimilation rates plateaued, which typically occurred within two to three minutes. We took these measurements from July $26^{\text {th }}$ to August $2^{\text {nd }}$ in 2016 and from July $4^{\text {th }}$ to July $14^{\text {th }}$ in 2017 , with phytometers of the same species measured on the same day to reduce potential temporal differences in performance between treatments. We also measured the amount of PAR reaching the top of each phytometer relative to the incident PAR above the canopy using a LI-1500 Light Sensor Logger coupled with two LI-190R quantum sensors (Li-Cor Biosciences, Lincoln, NE, USA). These sensors were deployed to take simultaneous readings from above the canopy and at the top of the phytometer to most accurately calculate the percent of incoming PAR intercepted by the canopy. PAR measurements were taken on cloudless days, between 09:00 and 15:00 h. 
To compare a proportion of the aboveground biomass produced by each species over the growing season, we we clipped each phytometer at the base of the stem right before peak aboveground biomass occurred in early August of 2016 and mid-July of 2017. Research in these marshes determined that peak biomass for emergent marsh, meadow marsh, and P. australis vegetation communities occurred in mid-August 2016 and late July 2017 (Yuckin and Rooney 2019). Due to clonal origin of the phytometers and the extent of interweaving of roots and rhizomes within the upper $40 \mathrm{~cm}$ of sediment (Lei et al. 2019 ), below-ground biomass could not be accurately determined.

\section{Resource Measurements}

To characterize niche overlap among species, we collected environmental variables from sites dominated by each of the phytometer species: $P$. australis $(\mathrm{n}=$ 15), Typha spp. $(n=15), C$. aquatilis $(n=15)$ and $C$. canadensis $(n=15)$ for a total of 60 sites. For resident species, we selected patches of remnant vegetation at equivalent water depths but not experiencing direct interactions with $P$. australis to best approximate their realized niche within the marsh. Sites for each species were a minimum of 10 meters from one another, and all of the sites were situated within 1000 m of the phytometers (Appendix A). At each site we collected a $10 \mathrm{~cm}$ deep soil core to measure soil nutrients, measured soil moisture using a WET sensor kit and HH2 moisture meter (Delta-T Devices, Burlington, ON), and the measured the percent of incident PAR intercepted by the canopy by deploying the Li-Cor sensors to take simultaneous readings from the top of the canopy and the soil or water surface on cloudless days between 09:00 and 15:00 $\mathrm{h}$.

\section{Laboratory Analyses}

Each phytometer was dried at $80^{\circ} \mathrm{C}$ for 24 hours and then weighed on an analytical balance to the nearest $0.0001 \mathrm{~g}$ to determine the aboveground biomass. For a subset of 48 phytometers from the 2016 season: ten individuals of each of the resident species ( 5 'with competition,' and 5 'without competition') ( $10 \times 3$ $=30$ samples), and six P. australis phytometers ( 3 'with competition,' 3 'without competition') for each of the neighbouring species ( $6 \times 3=18$ samples), we also measured the carbon (\% dry weight) and nitrogen (\% dry weight) content from selected leaves. To relate these nutrient content measures to photosynthetic performance (e.g., Hirose and Werger 1987; Hirtreiter and Potts 2012), we also measured the $\delta^{13} \mathrm{C}$ isotopic composition of each selected leaf. The plants in our study are all $\mathrm{C}_{3}$ photosynthesizers which have $\delta^{13} \mathrm{C}$ values that range between -20 to $-37 \%$ o (Kohn 2010). The $C_{3}$ photosynthetic pathway discriminates against the heavier ${ }^{13} \mathrm{C}$ isotope during stomatal diffusion and carboxylation by Rubisco (Fry 1992) - plants that discriminate less between $\mathrm{C}$ isotopes typically photosynthesize more efficiently and have a higher (less negative) $\delta^{13} \mathrm{C}$ value (Farquhar et al. 1989; McAlpine et al. 2008).

Selected leaves were ground into a homogenous powder and a subsample of $1 \mathrm{mg}$ collected for analysis of $\mathrm{C}, \mathrm{N}$ and $\delta^{13} \mathrm{C}$ by the Environmental Isotope Laboratory at the University of Waterloo. First, samples underwent combustion conversion to gas through a 1108 Elemental Analyzer (Fisons Instruments) coupled to a Delta Plus XL (Thermo-Finnigan, Germany) continuous flow isotope ratio mass spectrometer. The \% $\mathrm{N}$ and $\% \mathrm{C}$ element content is a bulk measurement based on the sample weight against known certified elemental standards. The $\delta^{13} \mathrm{C}$ values were corrected to the primary reference scale of Vienna Pee Dee Belemnite. Every fifth sample was duplicated for precision quality control/quality assurance. Three of the duplicate samples (two $C$. canadensis, one $P$. australis) were outside of the calibration range and were removed from the dataset, leaving seven duplicates for precision analysis. Analytical precision was measured using relative percent difference between duplicates (EPA 2014), and the average precision was $0.002 \%$ ( \pm 0.113 st. error) for $\delta^{13} \mathrm{C}, 3.25 \%$ ( \pm 3.12 st. error) for $\% \mathrm{C}, 4.89 \%$ ( \pm 3.83 st. error) for $\% \mathrm{~N}$.

Soil samples collected for resource measurements were dried at $80^{\circ} \mathrm{C}$, ground into a homogenous mixture, then analyzed for soil pH, phosphorus (mg/ $\mathrm{Kg}$ ), carbon (\% dry weight), total nitrogen (\% dry weight), calcium (mg/Kg), potassium (mg/Kg), magnesium (mg/Kg), sodium (mg/Kg), copper (mg/Kg), iron $(\mathrm{mg} / \mathrm{Kg})$, zinc $(\mathrm{mg} / \mathrm{Kg}$ dry $)$, manganese $(\mathrm{mg} / \mathrm{Kg})$, and sulfur $(\mu \mathrm{g} / \mathrm{g})$. Plant available phosphorus was measured using sodium bicarbonate-extractable phosphorus following Reid (1998). Total nitrogen (TN) and carbon were measured using thermal conductivity detection (Reid 1998). The K, Mg, Ca, and Na samples were extracted using 1.0 N Ammonium Acetate solution, following Simard (1993). Copper, iron, and zinc samples were extracted using a 0.005M DTPA solution and the filtrate was analyzed by ICP-OES following Liang and Karamanos (1993). Manganese was measured using $0.1 \mathrm{~N}$ phosphoric acid as the extracting solution, following Reid (1998). For sulfur, homogenized samples were closed-vessel microwave digested with nitric acid and hydrochloric acid, then the microwave digested sample was brought to volume with Nanopure water and quantification was performed using ICP-OES (AOAC 2011.14). Nitrogen and carbon analyses were done at the Biogeochemical Analytical Service Laboratory at the University of Alberta while the other nutrient analyses were conducted by the Agriculture and Food Laboratory at the University of Guelph.

\section{Statistical Analyses}

We determined that year did not influence plant biomass (general linear model $F_{1,164}=2.40, p=0.123$ ) or carbon assimilation rates at full sunlight ( $1500 \mu$ mol $\mathrm{s}^{-1} \mathrm{~m}^{-2}$ ) (general linear model $\mathrm{F}_{1,164}=0.004, \mathrm{p}=0.948$ ), so we pooled the data from both years for these variables. We used two-way ANOVAs to compare carbon assimilation rates and water use efficiency at $1500 \mu \mathrm{mol} \mathrm{s} \mathrm{m}^{-1}$ among species and between the treatments. We ran four models in total with either carbon assimilation rate or water use efficiency as the response variable, with an interaction between phytometer species (for resident phytometers) or phytometer neighbours (for $P$. australis phytometers) and treatment (with or without competition). We used the same model design to assess differences in $\delta^{13} \mathrm{C}$. Duplicates in the $\delta^{13} \mathrm{C}$ data were averaged to one value for analyses. We used Type III sums of squares, unless an interaction was not significant, then we report Type II sums of squares. If a fixed factor was significant, without a significant interaction term, we used Tukey's HSD post-hoc test to assess differences among levels of the factor. Analyses were performed using the carpackage (Fox and Weisberg 2019) and agricolae (de Mendiburu 2020).

To evaluate the allocation of resources to above-ground biomass between treatments, we compared the yield of phytometers growing with competition to those growing without competition. Using the phytometers that were paired by height at the beginning of the experiment, we calculated differences in aboveground yield using the relative competition index (RCl) approach (Grace 1995; Goldberg et al. 1999; Vilà and Weiner 2004): 
$\left(Y_{\text {without competition }}-Y_{\text {with competition }}\right) / Y_{\text {without competition }}$

Yield $(Y)$ represents the above-ground biomass of each phytometer. As the weights are standardized, values greater than 0 , with a maximum of 1 , indicate that the above-ground biomass of the plant growing with competition was lower than its counterpart growing without competition. Values $<0$ indicate the aboveground biomass of the plant growing with competition was higher than its counterpart growing without competition. This allows us to compare the differences in above-ground yield among the species while accounting for variation in size among species.

The soil data, except $\mathrm{pH}$ and light, collected from the unmanipulated sites were converted to $\mathrm{ppm}$ (i.e., $\mathrm{mg} / \mathrm{Kg}$ ) and log transformed to improve normality. To control for collinearity among environmental variables, we summarized the underlying correlation structure using principal components analysis (PCA). We created a matrix of soil nutrients, $\mathrm{pH}$, soil moisture, and proportion of incident PAR reaching the ground and conducted the PCA, with a correlation matrix, using the rda function in vegan (Oksanen et al. 2020). The PCA scores were then multiplied by the proportion of variance explained by each axis, to give them appropriate weight, and were used as an indicator of ecological niche to quantify trophic niche region and overlap among the plant species using nicheROVER (Lysy et al. 2017). To estimate pairwise niche overlap, nicheROVER employs a Bayesian framework to calculate the probability that an individual from species $A$ is found in the niche region (a 95\% probability region in multivariate space) of species B (Swanson et al. 2015). All analyses were performed using R v. 4.0.3 (R Core Team 2020).

\section{Results}

\section{Resident species carbon assimilation rates}

Carbon assimilation rates in resident species showed a marked effect of competition (Fig. 1). From PAR levels $200 \mu \mathrm{mol} \mathrm{s}^{-1} \mathrm{~m}^{-2}$ to $1500 \mu \mathrm{mol} \mathrm{s} \mathrm{m}^{-2}$ carbon assimilation rates were higher in resident species growing without above-ground competition with $P$. australis compared to those growing with competition (Fig. 1A). While there was no interaction between species and treatment (two-way ANOVA $F_{2,91}=0.759, p=0.471$ ), all three resident species had higher carbon assimilation rates at $1500 \mu \mathrm{mol} \mathrm{s}^{-1} \mathrm{~m}^{-2}$ PAR when they were growing without competition (two-way ANOVA $F_{1,91}=33.52, \mathrm{p}<0.001 ;$ Table 1 \& 2). There was also a significant difference in carbon assimilation rates among the resident species (two-way ANOVA $F_{2,91}=38.720, p<0.001$ ). Typha spp. had carbon assimilation rates that were significantly higher than either $C$. canadensis or $C$. aquatilis (Table 1). Photosynthetic water use efficiency followed the same pattern as carbon assimilation rates (Table $1 \& 2$ ). Water use efficiency was higher in the treatments without competition, while Typha spp. had significantly higher WUE than $C$. canadensis, and the WUE of $C$. aquatilis was intermediate (Appendix E).

Phragmites australis carbon assimilation and water use efficiency

There was no difference in carbon assimilation rates for $P$. australis growing with or without competition (Fig. 1B). There was no significant interaction between neighbouring species or treatment (two-way ANOVA $F_{2,63}=0.615, p=0.544$ ), and neither treatment (two-way ANOVA $\left.F_{1,63}=2.80, p=0.099\right)$ or neighbouring species (two-way ANOVA $F_{2,63}=1.459, \mathrm{p}=0.240$; Table 2) were significant predictors of carbon assimilation rates in $P$. australis. The average carbon assimilation rate of $P$. australis at $1500 \mu \mathrm{mol} \mathrm{s}{ }^{-1} \mathrm{~m}^{-2}$ was similar to Typha spp., and considerably higher than $C$. aquatilis or $C$. canadensis (Table 1). Water use efficiency was significantly higher in the 'no competition' treatment (two-way ANOVA $F_{1,63}=4.036 \mathrm{p}=0.0488$; Table 2 ) and, overall, was higher than the three resident species (Table $1 \&$ Appendix E).

\section{Above ground biomass \& PAR}

Unlike carbon assimilation, above-ground biomass did not exhibit a clear effect of competition. Carex aquatilis phytometers (average 0.156 ( \pm 0.07 st. error)) produced less above-ground biomass when growing with competition from $P$. australis. In contrast, $C$. calamagrostis (average -0.651 ( \pm 0.55 st. error)) and Typha spp. (average - 0.002 ( \pm 0.17 st. error)) both produced more above-ground biomass when growing with competition from $P$. australis. All of the $P$. australis phytometers produced more above-ground biomass when growing with competition from $C$. canadensis (average $\mathrm{RCl}-0.223$ ( \pm 0.22$)$ ), $C$. aquatilis (average $\mathrm{RCl}-0.329( \pm 0.52)$ ) and Typha spp. (average $\mathrm{RCl}-0.233( \pm 0.16)$ ) (Appendix F).

The average amount of PAR reaching resident species and $P$. australis phytometers was higher when growing without competition (Table $1 ;$ Appendix $G)$. Both $P$. australis (average height $156 \mathrm{~cm}$ ( \pm 2.99 st. error)) and Typha spp. (average height $186 \mathrm{~cm}$ ( \pm 5.39 st. error) are larger species than resident meadow species C. canadensis (average height $93.1 \mathrm{~cm}( \pm 1.68 \mathrm{st}$. error)) and C. aquatilis (average height $98.9 \mathrm{~cm}( \pm 1.59$ st. error)). As such, $P$. australis and Typha spp. generated more above-ground biomass (Table 1; Appendix G) and gained height more quickly over the field season than $C$. canadensis or $C$. aquatilis. On average, phytometers growing without competition were shorter than those growing with competition (Appendix H).

\section{Resident species foliar nutrient content and isotopes}

Overall, resident species in both treatments had lower nitrogen to carbon ratios than invasive $P$. australis phytometers growing without competition (Fig. $3 \mathrm{~A}$ ). Carbon content in the leaves of resident species did not have a significant interaction between species and treatment, nor was treatment significant (Table 2). However, there was a significant difference in carbon content among the species (two-way ANOVA $F_{2,23}=27.31, p<0.01$ ). The carbon content in Typha spp. was significantly higher than $C$. aquatilis, while $C$. canadensis was intermediate (Table 1). Nitrogen content in the leaves of resident species exhibited a significant interaction between species and treatment (two-way ANOVA $F_{2,23}=3.770, p=0.038$ ). Nitrogen content in $C$. aquatilis and $C$. canadensis increased when phytometers grew without competition, while Typha spp. nitrogen content decreased when growing without competition (Table 1).

There was no significant interaction between resident species and treatment for $\delta^{13} \mathrm{C}$, but both species and treatment were significant predictors of $\delta^{13} \mathrm{C}$ values (Table 2). The average $\delta^{13} \mathrm{C}$ value in Typha spp. leaves was significantly lower than $C$. aquatilis and $C$. canadensis (Table 1 ). The average $\delta^{13} \mathrm{C}$ value 
for phytometers growing with competition was lower than those without competition.

Phragmites australis foliar nutrient content and isotopes

For $P$. australis phytometers, carbon content among neighbouring species did not differ between treatments, nor among neighbouring species $\left(\mathrm{F}_{2,12} \leq 3.576, \mathrm{p}\right.$ $\geq 0.083$; Fig. 2.3C, Table 2.2). The average carbon content in $P$. australis was lower than Typha spp., but similar to $C$. aquatilis (Table 1). The nitrogen content in $P$. australis phytometers differed significantly between treatments, but the interaction term and neighbours were not significant predictors (Table 2). The nitrogen content in phytometers growing without competition was significantly higher than those growing with competition (Table 1). The interaction term and fixed factors were not significant predictors of $\delta^{13} \mathrm{C}$ values $P$. australis phytometers (Table 2).

Table 1. Averages and standard errors for response variables for each phytometer and treatment: percent of incident photosynthetically available radiation ( $\mu \mathrm{mol} \mathrm{s} \mathrm{m}^{-1}$ ) (PAR) reaching each phytometer; the amount of above-ground biomass ( $\mathrm{g}$ ) generated by each phytometer; carbon assimilation rate $\left(\mu \mathrm{mol} \mathrm{CO} \mathrm{C} \mathrm{s}^{-1} \mathrm{~m}^{-2}\right)$ (A) at $1500 \mu \mathrm{mol} \mathrm{s} \mathrm{m}^{-2} \mathrm{PAR}$; water use efficiency $\left(\mathrm{CO}_{2} \mathrm{mmol} \mathrm{s}^{-1} \mathrm{~m}^{-2} \mathrm{H}_{2} 0\right)$ (WUE) at $1500 \mu \mathrm{mol} \mathrm{s} \mathrm{m}^{-2} \mathrm{PAR}$; foliar carbon (\%C), foliar nitrogen $(\% \mathrm{~N})$, and $\delta^{13} \mathrm{C}$ values from leaves.

\begin{tabular}{|c|c|c|c|c|c|c|c|}
\hline & & $\begin{array}{l}\text { Calamagrostis } \\
\text { candensis }\end{array}$ & $\begin{array}{c}\text { Carex } \\
\text { aquatilis }\end{array}$ & Typha spp. & $\begin{array}{l}\text { Phragmites } \\
\text { australis and } \\
\text { C. canadensis }\end{array}$ & $\begin{array}{l}\text { Phragmites } \\
\text { australis and } \\
\text { C. aquatilis }\end{array}$ & $\begin{array}{l}\text { Phragmites australis and } \\
\text { Typha spp. }\end{array}$ \\
\hline \multirow[t]{2}{*}{$\overline{\mathrm{AR}} \%$} & $\begin{array}{l}\text { Without } \\
\text { competition }\end{array}$ & $67.0( \pm 6.51)$ & $\begin{array}{l}50.0( \pm \\
5.47)\end{array}$ & $\begin{array}{l}90.0( \pm \\
2.14)\end{array}$ & $91.6( \pm 2.35)$ & $90.6( \pm 2.00)$ & $94.4( \pm 1.86)$ \\
\hline & Competition & $40.4( \pm 6.74)$ & $\begin{array}{l}41.4( \pm \\
6.78)\end{array}$ & $\begin{array}{l}75.2( \pm \\
7.03)\end{array}$ & $77.3( \pm 8.37)$ & $82.6( \pm 7.54)$ & $93.7( \pm 1.63)$ \\
\hline \multirow[t]{4}{*}{$\begin{array}{l}\text { iomass } \\
\text { ¡) }\end{array}$} & $\begin{array}{l}\text { Without } \\
\text { competition }\end{array}$ & $2.24( \pm 0.541)$ & $\begin{array}{l}2.2( \pm \\
0.223)\end{array}$ & $\begin{array}{l}38.8( \pm \\
2.38)\end{array}$ & $25.7( \pm 4.59)$ & $16.7( \pm 2.19)$ & $21.1( \pm 2.89)$ \\
\hline & Competition & $1.47( \pm 0.161)$ & $\begin{array}{l}2.0( \pm \\
0.305)\end{array}$ & $\begin{array}{l}36.3( \pm \\
3.60)\end{array}$ & $27.8( \pm 4.96)$ & $15.2( \pm 3.19)$ & $19.6( \pm 2.32)$ \\
\hline & $\begin{array}{l}\text { Without } \\
\text { competition }\end{array}$ & $13.2( \pm 0.69)$ & $\begin{array}{l}14.9( \pm \\
0.94)\end{array}$ & $\begin{array}{l}20.7( \pm \\
1.65)\end{array}$ & $18.8( \pm 0.91)$ & $21.4( \pm 1.16)$ & $19.9( \pm 1.09)$ \\
\hline & Competition & $8.7( \pm 0.51)$ & $\begin{array}{l}9.2( \pm \\
1.14)\end{array}$ & $\begin{array}{l}17.6( \pm \\
1.28)\end{array}$ & $18.3( \pm 1.06)$ & $18.3( \pm 1.03)$ & $21.3( \pm 2.05)$ \\
\hline \multirow[t]{2}{*}{ TUE } & $\begin{array}{l}\text { Without } \\
\text { competition }\end{array}$ & $2.2( \pm 0.09)$ & $\begin{array}{l}2.44( \pm \\
0.09)\end{array}$ & $\begin{array}{l}2.42( \pm \\
0.20)\end{array}$ & $3.11( \pm 0.16)$ & $3.02( \pm 0.10)$ & $3.32( \pm 0.14)$ \\
\hline & Competition & $1.9( \pm 0.09)$ & $\begin{array}{l}1.85( \pm \\
0.19)\end{array}$ & $\begin{array}{l}2.35( \pm \\
0.12)\end{array}$ & $2.94( \pm 0.12)$ & $2.82( \pm 0.08)$ & $3.05( \pm 0.15)$ \\
\hline \multirow[t]{2}{*}{ C } & $\begin{array}{l}\text { Without } \\
\text { competition }\end{array}$ & $47.3(0.82)$ & $46.0(0.16)$ & $\begin{array}{l}48.9 \\
(0.55)\end{array}$ & $46.8( \pm 0.23)$ & $46.1( \pm 0.62)$ & $46.7( \pm 0.83)$ \\
\hline & Competition & $47.7(0.70)$ & $46.1(0.56)$ & $\begin{array}{l}47.9 \\
(0.61)\end{array}$ & $47.0( \pm 0.49)$ & $47.4( \pm 0.47)$ & $47.7( \pm 0.41)$ \\
\hline \multirow[t]{2}{*}{$\mathrm{N}$} & $\begin{array}{l}\text { Without } \\
\text { competition }\end{array}$ & $1.1(0.10)$ & $0.8(0.10)$ & $2.0(0.24)$ & $2.4( \pm 0.19)$ & $2.6( \pm 0.13)$ & $2.5( \pm 0.34)$ \\
\hline & Competition & $1.8(0.09)$ & $1.1(0.16)$ & $1.7(0.28)$ & $1.7( \pm 0.14)$ & $1.8( \pm 0.06)$ & $1.8( \pm 0.28)$ \\
\hline \multirow[t]{2}{*}{${ }^{13} \mathrm{C}$} & $\begin{array}{l}\text { Without } \\
\text { competition }\end{array}$ & $-27.9(0.51)$ & $\begin{array}{l}-28.8 \\
(0.38)\end{array}$ & $\begin{array}{l}-30.0 \\
(0.36)\end{array}$ & $-26.5( \pm 0.66)$ & $-26.4( \pm 0.60)$ & $-26.1( \pm 0.44)$ \\
\hline & Competition & $-27.0(0.39)$ & $\begin{array}{l}-27.8 \\
(0.22)\end{array}$ & $\begin{array}{l}-29.2 \\
(0.28) \\
\end{array}$ & $-27.0( \pm 0.50)$ & $-27.0( \pm 0.16)$ & $-26.4( \pm 0.40)$ \\
\hline
\end{tabular}

Table 2. ANOVA results for carbon assimilation ( $\mu \mathrm{mol} \mathrm{CO} \mathrm{C} \mathrm{s}^{-1} \mathrm{~m}^{-2}$ ) (A) and water use efficiency $\left(\mathrm{CO}_{2} \mathrm{mmol} \mathrm{s}^{-1} \mathrm{~m}^{-2} \mathrm{H}_{2} 0\right)(\mathrm{WUE})$ at 1500 $\mu \mathrm{mol} \mathrm{s} \mathrm{m}^{-1} \mathrm{PAR}$, percent carbon $(\% \mathrm{C})$, nitrogen $(\% \mathrm{~N})$, and $\delta^{13} \mathrm{C}$ values from phytometer leaves. Resident species phytometers $(C$. aquatilis, C. canadensis, Typha spp.) or P. australis phytometer neighbours (C. aquatilis, C. canadensis, Typha spp.) and treatment (with competition or without competition) as fixed factors. 


\begin{tabular}{|c|c|c|c|c|c|c|c|c|c|c|c|c|c|c|c|c|c|c|c|c|}
\hline & \multicolumn{10}{|c|}{ Resident species phytometers } & \multicolumn{10}{|c|}{ Phragmites australis phytometers } \\
\hline & \multicolumn{3}{|c|}{ Species } & \multicolumn{3}{|c|}{ Treatment } & \multicolumn{3}{|c|}{ Spp x Treatment } & \multirow[t]{2}{*}{ Residual } & \multicolumn{3}{|c|}{ Neighbours } & \multicolumn{3}{|c|}{ Treatment } & \multicolumn{3}{|c|}{$\begin{array}{l}\text { Neighbour } \mathrm{x} \\
\text { Treatment }\end{array}$} & \multirow[t]{2}{*}{ Resid } \\
\hline & $\mathrm{df}$ & $\mathrm{F}$ & $\mathrm{p}$ & $\mathrm{df}$ & $\mathrm{F}$ & $\mathrm{p}$ & $\mathrm{df}$ & $\mathrm{F}$ & $\mathrm{p}$ & & $\mathrm{df}$ & $\mathrm{F}$ & $\mathrm{p}$ & $\mathrm{df}$ & $\mathrm{F}$ & $\mathrm{p}$ & $\mathrm{df}$ & $\mathrm{F}$ & $\mathrm{p}$ & \\
\hline A & 2 & 38.72 & $<0.001$ & 1 & 33.52 & $<0.001$ & 2 & 0.76 & 0.471 & 91 & 2 & 1.45 & 0.240 & 1 & 2.80 & 0.099 & 2 & 0.62 & 0.544 & 63 \\
\hline WUE & 2 & 3.15 & 0.048 & 1 & 9.22 & 0.003 & 2 & 1.74 & 0.182 & 91 & 2 & 2.03 & 0.140 & 1 & 4.04 & 0.048 & 2 & 0.06 & 0.938 & 63 \\
\hline$\% \mathrm{C}$ & 2 & 8.23 & 0.002 & 1 & 0.138 & 0.714 & 2 & 0.730 & 0.493 & 23 & 2 & 0.32 & 0.730 & 1 & 3.58 & 0.083 & 2 & 0.57 & 0.581 & 12 \\
\hline$\% \mathrm{~N}$ & 2 & 11.54 & $<0.001$ & 1 & 6.32 & 0.019 & 2 & 3.77 & 0.038 & 23 & 2 & 0.46 & 0.641 & 1 & 18.78 & $<0.001$ & 2 & 0.01 & 0.991 & 12 \\
\hline$\delta^{13} \mathrm{C}$ & 2 & 17.92 & $<0.001$ & 1 & 10.34 & 0.004 & 2 & 0.05 & 0.956 & 23 & 2 & 0.56 & 0.584 & 1 & 1.39 & 0.262 & 2 & 0.04 & 0.963 & 12 \\
\hline
\end{tabular}

\section{Niche space and niche overlap}

The first two axes of the PCA accounted for $73.6 \%$ of the variance in the data (Axis 1: 0.648, Axis 2: 0.086 (Appendix I)), and were selected based on a scree plot assessing inertia (Appendix J). PCA axis 1 illustrates a clear gradient among the three resident species, reflecting the partitioning of their associated "remnant" vegetation communities along the water depth gradient (Fig. 3). Calamagrostis canadensis is on one end with the lowest average soil moisture (73.6 \% ( \pm 1.53 st. error, coefficient of variation $8.1 \%)$, while C. aquatilis (79.2\% ( \pm 0.93 st. error, coefficient of variation $4.5 \%)$ ) and Typha spp. $(82.0 \%$ ( \pm 1.29 st. error, coefficient of variation $6.1 \%)$ ) were typically inundated. Phragmites australis sites had greater variation in soil moisture, with an average of $78.2 \%$ but \pm 3.84 st. error, coefficient of variation $19.0 \%$. Soils where Typha spp. dominated also had the highest concentrations of phosphorus (35.6 mg/kg ( $\pm 5.23 \mathrm{st}$. error)), potassium $(128.6 \mathrm{mg} / \mathrm{kg}( \pm 0.11 \mathrm{st}$. error)), and nitrogen $(11,066.7 \mathrm{mg} / \mathrm{kg}( \pm 1277.26 \mathrm{st}$. error $))$, while soils where $C$. canadensis dominated had the lowest concentration of these three nutrients (P: $9.2 \mathrm{mg} / \mathrm{Kg}$ ( \pm 0.75 st. error), K: $34.15 \mathrm{mg} / \mathrm{kg}( \pm 0.3 .05 \mathrm{st}$. error), N: $1780 \mathrm{mg} / \mathrm{kg}( \pm 154.06 \mathrm{st}$. error)). PCA axis 2 seems to illustrate a gradient between incident light reaching the ground. The average incident PAR reaching the ground was $16.07 \%$ ( \pm 5.81 st. error) in stands of $C$. aquatilis, $8.09 \%$ ( \pm 2.09 st. error) in stands of $C$. canadensis, $6.21 \%$ ( \pm 1.55 st. error) in stands of Typha spp., and $2.76 \%$ ( \pm 0.83 st. error) in stands of $P$. australis.

Phragmites australis had the largest niche region of the four species, followed by Typha spp., $C$. aquatilis, then $C$. canadensis (Table 3). The probability of $P$. australis overlapping with the niche space of $C$. aquatilis and Typha spp. was higher than the probability of overlap with $C$. canadensis. However, the probability of overlap of the three resident species onto the niche of $P$. australis was considerably higher (Table 3, Appendix K).

Table 3. Estimated niche region size, with standard error, and median overlap of 95\% niche region with $95 \%$ credible intervals for invasive $P$. australis and resident $C$. canadensis, $C$. aquatilis, and Typha spp. based on PCA scores. Values indicate the overlap probability of species A onto the niche of species B.

\begin{tabular}{|c|c|c|c|}
\hline Species A & 95\% Niche Region & Species B & Median \& 95\% CI \\
\hline \multirow[t]{3}{*}{ Calamagrostis canadensis } & $0.077( \pm 0.021)$ & Carex aquatilis & $20.2(0-83)$ \\
\hline & & Typha spp. & $0.0(0-34)$ \\
\hline & & Phragmites australis & $83.6(25-100)$ \\
\hline \multirow[t]{3}{*}{ Carex aquatilis } & $0.186( \pm 0.048)$ & Calamagrostis canadensis & $4.7(0-18)$ \\
\hline & & Typha spp. & $31.9(0-34)$ \\
\hline & & Phragmites australis & $94.9(73-100)$ \\
\hline \multirow[t]{3}{*}{ Typha spp. } & $0.304( \pm 0.083)$ & Calamagrostis canadensis & $0.1(0-2)$ \\
\hline & & Carex aquatilis & $16.5(3-51)$ \\
\hline & & Phragmites australis & $53.4(30-93)$ \\
\hline \multirow[t]{3}{*}{ Phragmites australis } & $0.360( \pm 0.098)$ & Calamagrostis canadensis & $8.3(2-22)$ \\
\hline & & Carex aquatilis & $64.3(42-87)$ \\
\hline & & Typha spp. & $53.5(22-84)$ \\
\hline
\end{tabular}

\section{Discussion}

Detrimental invasive species should exhibit high niche overlap and large fitness differences with resident species (MacDougall et al. 2009). We quantified differences in photosynthetic performance, competition for photosynthetically active radiation, and niche overlap between a globally successful, model invasive species, $P$. australis, and resident wetland species. Our results confirm that $P$. australis has high niche overlap with resident plant species, is not negatively affected by competition for above-ground resources with resident species and utilizes available resources more effectively than resident species. Direct competition with $P$. australis significantly reduced the photosynthetic performance of resident species, while competition with resident species did not negatively impact $P$. australis. Phragmites australis also has the largest niche region and was most likely to overlap onto the niche of $C$. aquatilis and $T y p h a$. Resident species had a higher probability of overlapping onto the niche space of $P$. australis, particularly the meadow marsh species $C$. canadensis and $C$. aquatilis. This finding agrees with historical records of the region that identified meadow marsh and grass/sedge hummock were frequently displaced by $P$. 
australis invasion (Wilcox et al. 2003). These results suggest $C$. canadensis and $C$. aquatilis could persist areas currently dominated by $P$. australis if it were removed, and their absence is due to exclusion by this invasive plant. This study represents an advancement in testing the effects of fitness and niche differences in the success of a perennial, rhizomatous invasive plant.

The carbon assimilation rate and water use efficiency of all three resident species were lower than $P$. australis and showed a decrease when growing with above-ground competition. Meadow marsh species $C$. canadensis and $C$. aquatilis assimilated considerably less carbon and were less efficient at generating biomass per unit water transpired (Farquhar et al. 1989) than $P$. australis, and competition decreased carbon assimilation and water use efficiency further. Over the growing season $C$. canadensis and $C$. aquatilis produced less above-ground biomass and did not grow as tall or as fast as $P$. australis, a commonality among many species in $P$. australis invaded wetlands. In both freshwater and brackish marshes in North America, $P$. australis consistently produces more above-ground biomass than other wetland plants in the same system (Meyerson et al. 2000). Typha, however, also grows quickly, produces extensive above-ground biomass (Bansal et al. 2019), and has carbon assimilation rates similar to $P$. australis. However, Typha exhibited a decrease in carbon assimilation due to above-ground competition with $P$. australis, while $P$. australis competing with Typha did not. Our measurement of percent incident light in abundant stands of each species demonstrated that $P$. australis intercepts more photosynthetically active radiation than any of the resident species, including Typha. Similar work in freshwater marshes found the same pattern in monocultures and mixed stands of Typha and $P$. australis - approximately $30 \%$ of full sunlight reached the litter layer in Typha stands compared to $10 \%$ in $P$. australis stands - which the authors attribute to the horizontal orientation of $P$. australis leaves (Hirtreiter and Potts 2012). While these values are higher than what we measured, they also observed the pattern of $P$. australis intercepting more sunlight than Typha.

While $P$. australis produces dense stands that reduce light availability for other species, it is also subject to self-shading. Once stands have reached sufficient density, smaller and thinner shoots die prematurely from within-stand competition for light (van Der Toorn and Mook 1982; Hara et al. 1993). Our experimental design did not assess intraspecific competition for PAR, but we can assess each species photosynthetic activity and whole plant function over the field season using $\delta^{13} \mathrm{C}$ values (Dawson et al. 2002). Phragmites australis had the highest (least negative) $\delta^{13} \mathrm{C}$ values (-26.58\%o \pm 0.18 st. error), indicating enrichment with the heavier carbon atoms and more efficient photosynthesis over the growing season (Farquhar et al. 1989). Resident species had lower $\delta^{13} \mathrm{C}$ values, and competition with $P$. australis resulted in lower average $\delta^{13} \mathrm{C}$ values for all resident species, coinciding with their lower photosynthetic water use efficiency (Fry 1992). While water availability is not a limiting factor for wetland plants, balancing the trade-off between carbon gain and water loss to transpiration is under the biological control of plants via stomatal conductance. When growing with competition, resident plants were less efficient at generating biomass per unit water transpired (Farquhar et al. 1989). This reduced efficiency may further negatively affect plants growing in competition as they allocate more resources to above-ground growth.

Many of the resident species growing with competition produced more above-ground biomass or were taller than their counterparts growing without competition. Measuring above-ground biomass has been used to assess effects of competition in the field (e.g., Güsewell and Edwards 1999), however this approach appears to account for flexibility in resource allocation and plant plasticity. Plants can respond to low light availability by allocating more resources to above-ground tissue, such as height and leaf area (Weiner 2004; Craine and Dybzinski 2013) but this trade-off has consequences. Allocating more resources to above-ground tissue can result in reduced net carbon gain per individual, as observed in our measurements of carbon assimilation, and it can impede the acquisition of water and soil nutrients, resulting in a diminished overall competitive ability (Aschehoug et al. 2016). The low nitrogen content in the leaves of $C$. canadensis and $C$. aquatilis growing with competition appear to support this relationship between competition, re-allocation of resources, and nutrient uptake. Uddin and William (2018) found that $P$. australisinvaded sites had higher concentrations of availble soil nutrients, including nitrogen and phosphorus, but $P$. austrails produced extensive belowground biomass and usurped nutrients from neighbouring species. This competition for soil resources, coupled with the need to grow taller, results in particularly challenging conditions for meadow marsh species. In species-rich fens in Switzerland, shading from $P$. australis did not appear to affect the performance of native species (Güsewell and Edwards 1999). However, plant performance was evaluated by clipping above-ground biomass (Güsewell and Edwards 1999) and based on our results this work may have missed that plants were compensating for reduced carbon assimilation when growing with $P$. australis by allocating more resources to aboveground tissue production. Working in the field, we did not have the same level of environmental control and homogeneity in conditions that can be achieved in the greenhouse, but the patterns we observed in carbon assimilation and compensatory aboveground tissue production indicate that collecting above-ground biomass in the field does not tell the full story of plant interactions, especially for rhizomatous plants.

In addition to more efficient photosynthesis, $P$. australis had a higher nitrogen to carbon ratio when growing without competition than the other resident species. Nitrogen is used in the creation of chloroplasts (Evans 1989) and plants can maximize photosynthetic efficiency by allocating more nitrogen to sunny leaves high in the canopy (Hirose and Werger 1987). High foliar nitrogen is commonly noted in $P$. australis studies (e.g., Yuckin and Rooney 2019), suggesting $P$. australis is more efficient at nitrogen uptake than other wetland species (Farnsworth and Meyerson 2003). When growing with competition, $P$. australis, $C$. aquatilis, and $C$. canadensis had lower amounts of foliar nitrogen while Typha exhibited an increase in foliar nitrogen content when growing with competition. There are multiple reasons this seemingly anomalous pattern could occur. One hypothesis is that $C$. canadensis and $C$. aquatilis were $\mathrm{N}$ limited when growing in competition with $P$. australis, due either to its usurpation of available $\mathrm{N}$ or to dilution, as they increased aboveground tissue production to compensate for PAR interception by $P$. australis. In contrast, Typha may be compensating for reduced PAR by increasing chloroplast production. The strategic allocation by Typha of nitrogen only to leaves in full sunlight has been documented in the field, while $P$. australis allocated similar amounts of nitrogen to leaves down the entire canopy, resulting in low $\mathrm{N}$ use efficiency (Hirtreiter and Potts, 2012). We suggest that future work strategically assesses the distribution of foliar nitrogen throughout the canopy of these species when growing with or without competition, to further refine this mechanistic understanding.

Competition with $P$. australis has a detrimental effect on resident plants, and the niches of resident species are very likely to overlap with the niche of $P$. australis. Resident species' niches were aligned along a gradient of standing water, with $C$. canadensis in areas with the lowest soil moisture and low nutrient concentrations and Typha in areas of high soil moisture, deep standing water, and high nutrient concentrations. This is typical of wetland vegetation communities, which align themselves along a topographical or moisture gradient from inundated flooded areas to shallow standing water (Keddy 2010 ). Of

Page $8 / 14$ 
the three resident species, Typha had the largest niche region. Typha x glauca and Typha angustifolia, a parent species of Typha x glauca, both have a wide global range, proliferate in high nutrient environments, and generate monocultures that alter wetland communities (Bansal et al. 2019). The large niche region of Typha in our study agrees with the well-documented niche breadth of this species. Typha $\mathrm{x}$ glauca and Typha angustifolia are also obligate wetland plants that are well adapted to deeper water and require a degree of consistent flooding (Bansal et al. 2019). This explains the low probability of niche overlap between Typha and meadow species $C$. aquatilis and C. canadensis, which preferentially establish in areas with shallower seasonal inundation (Darris 2006; Tilley et al. 2011). The median probability of niche overlap between Typha and $P$. australis were nearly identical for each species. When monospecific stands of Typha and $P$. australis grow together, $P$. australis usually displaces Typha (Paradis et al. 2014). A component of this successful displacement is likely the negative effect that competition with $P$. australis has on Typha carbon assimilation. While $P$. australis and Typha have many similarities and are both considered invasive in North American wetlands (Galatowitsch et al. 1999), their interactions are likely mediated by environmental conditions. Typha spp. prefer a consistent level of inundation and do not thrive with variability (e.g., (Boers and Zedler 2008; Wilcox and Nichols 2008), while $P$. australis populations increase with variable water depths (e.g., Wilcox et al. 2003).

Understanding the specific outcomes of plant interactions can inform the patterns we observe in the field. However, the results of species interactions are often attributed to competition despite numerous other mechanisms that can confer an advantage to an introduced species (e.g., Richardson and Pyšek 2006). While these were outside the scope of our study, our work adds to the growing body of literature about $P$. australis (Meyerson et al. 2016) that can assist us in better understanding how resident communities resist invasion and how invasive species maintain their prominence once they become established. In particular, functional traits (i.e., annual plants) and the diversity of resident plant communities can result in niche pre-emption and niche partitioning that confers biological resistance to communities that would otherwise be invaded by $P$. australis at the seedling stage (Byun et al. 2013). We recommend future experiments test the role of functional traits (e.g., annual plants, perennial rhizomatous plants, high growth rate or biomass production, high carbon assimilation, leaf nitrogen content) on coexistence using $P$. australis stands to better replicate how $P$. australis expands clonally once established via seeds (e.g., Kettenring et al. 2016). The methods employed in Paradis et al. (2014) present a mesocosm approach that could be adapted for this purpose. Future work should also build on the study presented here by integrating population level changes over a longer time period and explicitly measuring the differences between interspecific competition and intraspecific competition (e.g., Chesson 2000). This will produce a more robust understanding of the processes that allow $P$. australis to remain abundant in an invaded marsh and give additional insight into which native North American species, if any, can stably coexist with $P$. australis.

We expect that throughout its range $P$. australis has high niche overlap with resident species, and likely has additional fitness advantages (e.g., faster nutrient uptake, reduced predation relative to native species) over the species that it is replacing in wetlands. For ecologists and wetland managers who may be interested in creating native plant communities that are resistant to $P$. australis invasion, the ability of $P$. australis to usurp nitrogen, intercept light, and assimilate carbon more efficiently than many native species and its high niche overlap should be considered. Selecting native species with traits such as fast growth early in the season and the ability to rapidly capture carbon and nitrogen may allow resident species to better persist alongside $P$. australis. Based on our results, preventing $P$. australis from invading freshwater wetland communities such as sedge meadow and meadow marsh is imperative, as the shorter vegetation and high niche overlap with $P$. australis makes them especially vulnerable to displacement.

\section{Declarations}

Acknowledgements: We would like to thank those who helped with the field work for this project, including Graham Howell, Sarah Yuckin, Matthew Bolding, Heather Polowyk and Jessie Pearson.

Funding: This work was funded by Rooney's NSERC Discovery \#RGPIN-2014-03,846, Rooney's Early Researcher Award \#ER17-13-194 and the Ontario Ministry of Natural Resources and Forestry's non-consulting agreement MNRF-W-(12)3-16

Conflicts of interest/Competing interests: The authors have no competing interests to declare.

Availability of data and material:

1. Robichaud, Courtney; Rooney, Rebecca (2021): Leaf nutrient and isotope data. figshare. Dataset. https://doi.org/10.6084/m9.figshare.14737869.v2

2. Robichaud, Courtney; Rooney, Rebecca (2021): Phytometer biomass. figshare. Dataset. https://doi.org/10.6084/m9.figshare.14737878.v1

3. Robichaud, Courtney; Rooney, Rebecca (2021): Niche resource measurements. figshare. Dataset. https://doi.org/10.6084/m9.figshare.14737866.v1

4. Robichaud, Courtney; Rooney, Rebecca (2021): Carbon assimilation and WUE. figshare. Dataset. https://doi.org/10.6084/m9.figshare.14737857.v1

Code availability: Not applicable

\section{References}

1. Aschehoug ET, Brooker R, Atwater DZ et al (2016) The mechanisms and consequences of interspecific competition among plants. Annu Rev Ecol Evol Syst 47:263-281. https://doi.org/10.1146/annurev-ecolsys-121415-032123

2. Bansal S, Lishawa SC, Newman S et al (2019) Typha (Cattail) invasion in North American wetlands: Biology, regional problems, impacts, ecosystem services, and management. Wetlands

3. Boers AM, Zedler JB (2008) Stabilized water levels and Typha invasiveness. Wetlands 28:676-685. https://doi.org/10.1672/07-223.1

4. Byun C, de Blois S, Brisson J (2018) Management of invasive plants through ecological resistance. Biol Invasions 20:219-233.

https://doi.org/10.1007/s10530-017-1529-7

Page 9/14 
5. Byun C, de Blois S, Brisson J (2013) Plant functional group identity and diversity determine biotic resistance to invasion by an exotic grass. J Ecol 101:128-139. https://doi.org/10.1111/1365-2745.12016

6. Chambers RM, Meyerson LA, Saltonstall K (1999) Expansion of Phragmites australis into tidal wetlands of North America. Aquat Bot 64:261-273. https://doi.org/10.1016/S0304-3770(99)00055-8

7. Chesson $\mathrm{P}$ (2000) Mechanisms of maintenance of species diversity. Annu Rev Ecol Syst 31:343-366. https://doi.org/10.1146/annurev.ecolsys.31.1.343

8. Chesson P, Huntly N (1997) The roles of harsh and fluctuating conditions in the dynamics of ecological communities. Am Nat 150:519-553

9. Craine JM, Dybzinski R (2013) Mechanisms of plant competition for nutrients, water and light. Funct Ecol 27:833-840. https://doi.org/10.1111/13652435.12081

10. Darris D (2006) Plant guide for water sedge Calmagrostis canadensis. USDA- Nat Resour Conserv Serv Idaho Plant Mater Center

11. Dawson TE, Mambelli S, Plamboeck AH et al (2002) Stable isotopes in plant ecology. Annu Rev Ecol Syst 33:507-559.

https://doi.org/10.1146/annurev.ecolsys.33.020602.095451

12. de Mendiburu F (2020) agricolae: Statistical Procedures for Agricultural Research https://CRAN.R-project.org/package=agricolae

13. Elton C (1958) The Ecology of Invasions by Animals and Plants. Methuen, London

14. Environental Protection Agency (EPA) (2014) Chap. 1: Project Quality Assurance and Quality Control: 1-37

https://www.epa.gov/sites/production/files/2015-10/documents/chap1_1.pdf

15. Evans JR (1989) Photosynthesis and nitrogen relationships in leaves of C3 plants. Oecologia 78:9-19

16. Farnsworth EJ, Meyerson LA (2003) Comparative ecophysiology of four wetland plant species along a continuum of invasiveness. Wetlands 23:750-762

17. Farquhar GD, Ehleringer JR, Hubick KT (1989) Carbon isotope discrimination and photosynthesis. Annu Rev Plant Physiol Plant Mol Biol 40:503-537

18. Fox J, Weisberg S (2019) An $\{R\}$ Companion to Applied Regression, Third Edition

19. Fry B (1992) Stable isotope ecology. Springer, New York

20. Galatowitsch SM, Anderson NO, Ascher PD, Hall A (1999) Invasiveness in wetland plants in temperate north america. Wetlands 19:733-755. https://doi.org/10.1007/BF03161781

21. Gioria M, Osborne BA (2014) Resource competition in plant invasions: emerging patterns and research needs. Front Plant Sci 5:1-21. https://doi.org/10.3389/fpls.2014.00501

22. Goldberg D. DE, Rajaniemi T, Gurevitch J, Stewart-Oaten A (1999) Empirical approaches to quantifying interaction intensity: competition and facilitation along productivity gradients. Ecology 80:1118-1131

23. Grace JB (1995) On the measurement of plant competition intensity. Ecology 76:305-308

24. Güsewell S, Edwards P (1999) Shading by Phragmites australis: a threat for species-rich fen meadows? Appl Veg Sci 2:61-70. https://doi.org/10.2307/1478882

25. Hara T, van Der Toorn J, Mook J (1993) Growth dynamics and size structure of shoots of Phragmites australis, a clonal plant. J Ecol 81:47-60

26. Haslam SM (1971) Community Regulation in Phragmites communis Trin.: II. Mixed Stands. J Ecol 59:75-88

27. Hirose T, Werger MJA (1987) Maximizing daily canopy photosynthesis with respect to the leaf nitrogen allocation pattern in the canopy. Oecologia 520526

28. Hirtreiter JN, Potts DL (2012) Canopy structure, photosynthetic capacity and nitrogen distribution in adjacent mixed and monospecific stands of Phragmites australis and Typha latifolia. Plant Ecol 213:821-829. https://doi.org/10.1007/s11258-012-0044-2

29. Jung JA, Rokitnicki-Wojcik D, Midwood JD (2017) characterizing past and modelling future spread of Phragmites australis ssp. australis at Long Point Peninsula, Ontario, Canada. Wetlands 37:961-973. https://doi.org/10.1007/s13157-017-0931-3

30. Keane RM, Crawley MJ (2002) Exotic plant invasions and the enemy release hypothesis. Trends Ecol Evol 17:164-170

31. Keddy P (2010) Zonation: shorelines as a prism. In: Wetland Ecology: Principles and Conservation, 2nd edn. Cambridge University Press, Cambridge, pp 269-299

32. Kettenring KM, Mock KE, Zaman B, McKee M (2016) Life on the edge: reproductive mode and rate of invasive Phragmites australis patch expansion. Biol Invasions 18:2475-2495. https://doi.org/10.1007/s10530-016-1125-2

33. Kohn MJ (2010) Carbon isotope compositions of terrestrial C3 plants as indicators of (paleo)ecology and (paleo)climate. Proc Natl Acad Sci U S A 107:19691-19695. https://doi.org/10.1073/pnas.1004933107

34. Konisky RA, Burdick DM (2004) Effects of stressors on invasive and halophytic plants of New England salt marshes: A framework for predicting response to tidal restoration. Wetlands 24:434-447. https://doi.org/10.1672/0277-5212(2004)024[0434:EOSOIA]2.0.C0;2

35. Kraft NJB, Adler PB, Godoy 0 et al (2015) Community assembly, coexistence and the environmental filtering metaphor. Funct Ecol 29:592-599. https://doi.org/10.1111/1365-2435.12345

36. Lei C, Yuckin SJ, Rooney RC (2019) Rootding depth and below ground biomass in a freshwater coastal marsh invaded by European Reed (Phragmites australis) compared with remnant univaded sites at Long Point, Ontario. The Canadian Field-Naturalist 113:364-371

37. Levine J, D'Antonio CM (1999) Elton revisited: A Review of Evidence Linking Diversity and Invasibility. Oikos 87:15-26

38. Liang J, Karamanos RE (1993) DTPA-Extractable Fe, Mn, Cu, and ZN. In: Carter MR (ed) Soild Sampling and Methods of Analysis. Canadian Society of Soil Science. Lewis Publishers, pp 97-90 
39. Lysy M, Stasko AD, Swanson HK (2017) nicheROVER: (Niche) (R)egion and Niche (Over)lap Metrics for Multidimensional Ecological Niches https://CRAN.R-project.org/package=nicheROVER

40. Macarthur RH, Levins R (1967) The limiting similarity, convergence, and divergence of coexisting species. Am Nat 101:377-385

41. MacDougall AS, Gilbert B, Levine JM (2009) Plant invasions and the niche. J Ecol 97:609-615. https://doi.org/10.1111/j.1365-2745.2009.01514.x

42. McAlpine KG, Jesson LK, Kubien DS (2008) Photosynthesis and water-use efficiency: A comparison between invasive (exotic) and non-invasive (native) species. Austral Ecol 33:10-19. https://doi.org/10.1111/j.1442-9993.2007.01784.x

43. Meyerson LA, Chambers RM, Vogt KA (1999) The effects of Phragmites removal on nutrient pools in a freshwater tidal marsh ecosystem. Biol Invasions 1:129-136. https://doi.org/10.1023/a:1010005724468

44. Meyerson LA, Cronin JT, Pysek P (2016) Phragmites australis as a model organism for studying plant invasions. Biol Invasions 18:2421-2431. https://doi.org/10.1007/s10530-016-1132-3

45. Meyerson LA, Saltonstall K, Windham L et al (2000) A comparison of Phragmites australis in freshwater and brackish marsh environments in North America. Wetl Ecol Manag 8:89-103

46. Minchinton TE, Bertness MD (2003) Disturbance-mediated competition and the spread of Phragmites australis in a coastal marsh. Ecol Appl 13:14001416

47. Mozdzer TJ, Megonigal JP (2012) Jack-and-Master trait responses to elevated $\mathrm{CO}_{2}$ and N: A comparison of native and introduced Phragmites australis. PLoS One 7:. https://doi.org/10.1371/journal.pone.0042794

48. Oksanen J, Blanchet FG, Friendly M et al (2020) vegan: Community Ecology Package. R package version 2.5-7. https://CRAN.Rproject.org/package=vegan

49. Packer JG, Meyerson LA, Skálová H et al (2017) Biological flora of the British Isles: Phragmites australis. J Ecol 105:1123-1162. https://doi.org/10.1111/1365-2745.12797

50. Paradis E, Bellavance M-Ė, Fontaine B, Brisson J (2014) Interspecific competition for space between wetland plants with clonal growth. Wetlands 34:1003-1012. https://doi.org/10.1007/s13157-014-0564-8

51. Pearson DE, Ortega YK, Eren Ö, Hierro JL (2018) Community assembly theory as a framework for biological invasions. Trends Ecol Evol $33: 313-325$. https://doi.org/10.1016/j.tree.2018.03.002

52. Pieper S, Dorken M, Freeland J (2020) Genetic structure in hybrids and progenitors provides insight into processes underlying an invasive cattail (Typha $\times$ glauca) hybrid zone. Heredity 124:714-725. https://doi.org/10.1038/s41437-020-0307-y

53. R Core Team (2020) R: A language and environment for statistical computing. R Found Stat Comput Vienna, Austria

54. Reid K (1998) Soil Fertility Handbook, 3rd edn. Ontario Ministry of Agricultures, Food, and Rural Affairs (OMAFRA) publication

55. Richardson DM, Pyšek P (2006) Plant invasions: Merging the concepts of species invasiveness and community invasibility. Prog Phys Geogr 30:409431. https://doi.org/10.1191/0309133306pp490pr

56. Robichaud CD, Rooney RC (2021) Effective suppression of established invasive Phragmites australis leads to secondary invasion in a coastal marsh. Invasive Plant Science Management 14:9-19. https://doi.org/10.1017/inp.2021.2

57. Saltonstall K (2002) Cryptic invasion by a non-native genotype of the common reed, Phragmites australis, into North America. Proc Natl Acad Sci U S A 99:2445-2449. https://doi.org/10.1073/pnas.032477999

58. Simard RR (1993) Ammonium Acetate-Extractable Elements. Pages 39 to 42. In: Carter MR (ed) Soil Sampling and Methods of Analysis. Canadian Society of Soil Science. Lewis Publishers

59. Swanson HK, Lysy M, Power M et al (2015) A new probalilistic method for quantifying n-dimensional ecological niches and niche overlap. Ecology 96:318-324

60. Tilley D, Ogle D, St. John L (2011) Plant guide for water sedge Carex aquatilis. Aberdeen, ID. Published

61. Travis SE, Marburger JE, Windels S, Kubátová B (2010) Hybridization dynamics of invasive cattail (Typhaceae) stands in the Western Great Lakes Region of North America: A molecular analysis. J Ecol 98:7-16. https://doi.org/10.1111/j.1365-2745.2009.01596.x

62. Uddin N, William R (2018) Can nutrient enrichment influence the invasion of Phragmites australis? Sci Total Environ 613-614:1449-1459. https://doi.org/10.1016/j.scitotenv.2017.06.131

63. van Der Toorn J, Mook JH (1982) The influence of environmental factors and management on stands of Phragmites australis. 1. Effects of burning, frost and insect damage on shoot density and shoot. J Appl Ecol 19:477-499

64. Vasquez EA, Glenn EP, Brown JJ et al (2005) Salt tolerance underlies the cryptic invasion of North American salt marshes by an introduced haplotype of the common reed Phragmites australis (Poaceae). Mar Ecol Prog Ser 298:1-8. https://doi.org/10.3354/meps298001

65. Vilà M, Weiner J (2004) Are invasive plant species better competitors than native plant species?-evidence from pairwise experiments. Oikos 105:229238. https://doi.org/10.1111/j.0030-1299.2004.12682.x

66. Weiner J (2004) Allocation, plasticity and allometry in plants. Perspect Plant Ecol Evol Syst 6:207-215

67. Wilcox DA (2012) Response of wetland vegetation to the post-1986 decrease in Lake St. Clair water levels: Seed-bank emergence and beginnings of the Phragmites australis invasion. J Great Lakes Res 38:270-277. https://doi.org/10.1016/j.jglr.2012.02.007

68. Wilcox DA, Nichols SJ (2008) The effects of water-level fluctuations on vegetation in a Lake Huron wetland. Wetlands 28:487-501. https://doi.org/10.1672/07-129.1 
69. Wilcox KL, Petrie SA, Maynard LA, Meyer SW (2003) Historical distribution and abundance of Phragmites australis at Long Point, Lake Erie, Ontario. J Great Lakes Res 29:664-680. https://doi.org/10.1016/S0380-1330(03)70469-9

70. Yuckin S, Rooney R (2019) significant increase in nutrient stocks following Phragmites australis invasion of freshwater meadow marsh but not of cattail marsh. Front Environ Sci 7:1-16. https://doi.org/10.3389/fenvs.2019.00112

\section{Figures}

A
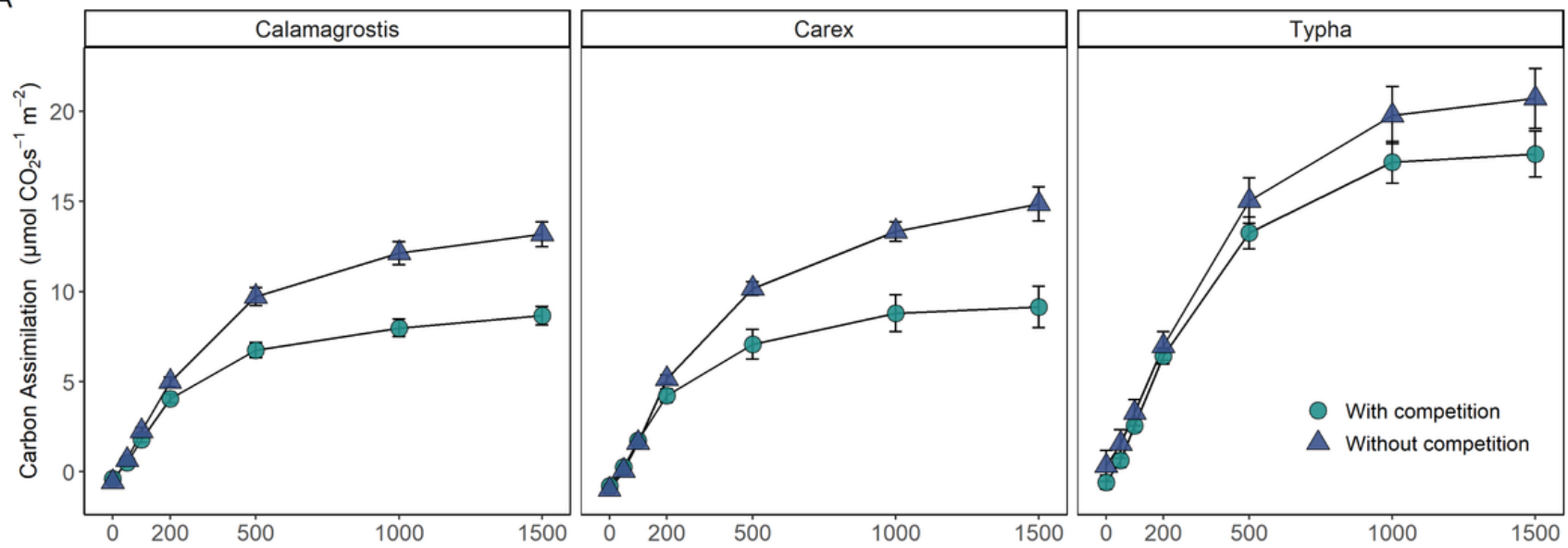

B
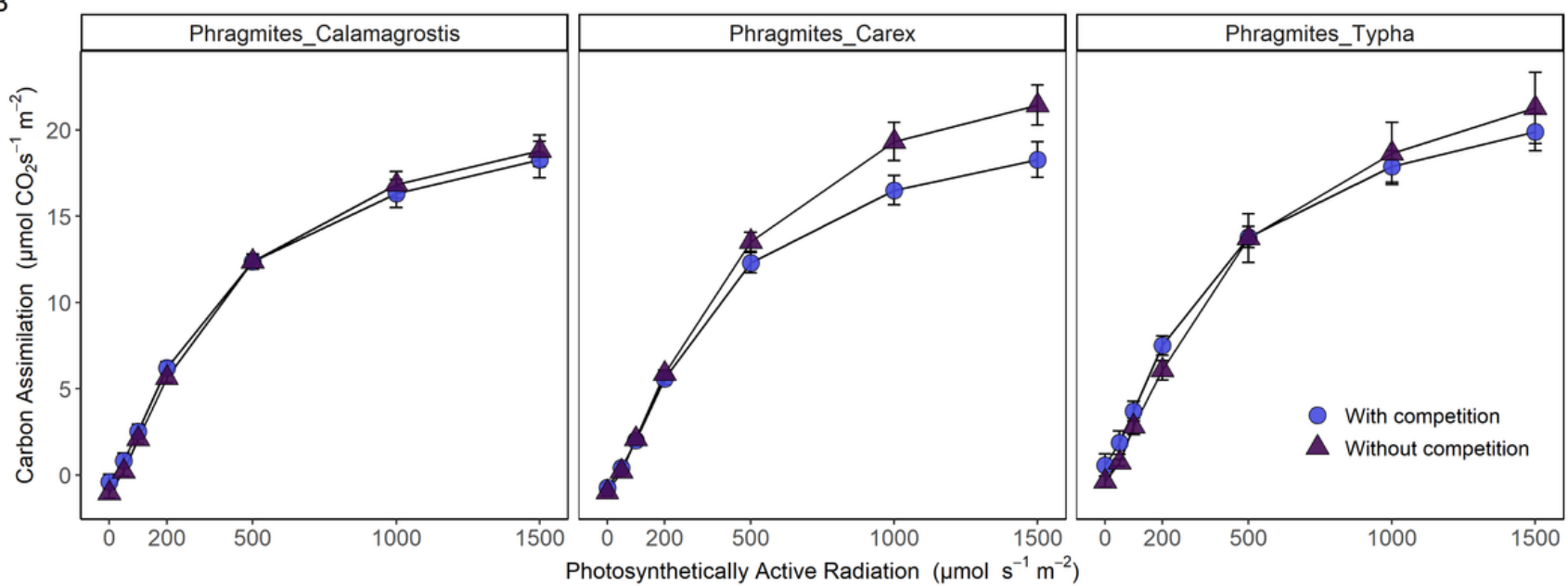

Figure 1

The carbon assimilation rates ( $\mu \mathrm{mol}$ CO2 s-1 m-2) at varying levels of photosynthetically active radiation ( $\mu \mathrm{mol} s-1 \mathrm{~m}-2)$ for resident plant species (A) and P. australis (B) with or without above-ground competition. Error bars represent standard error. 
A

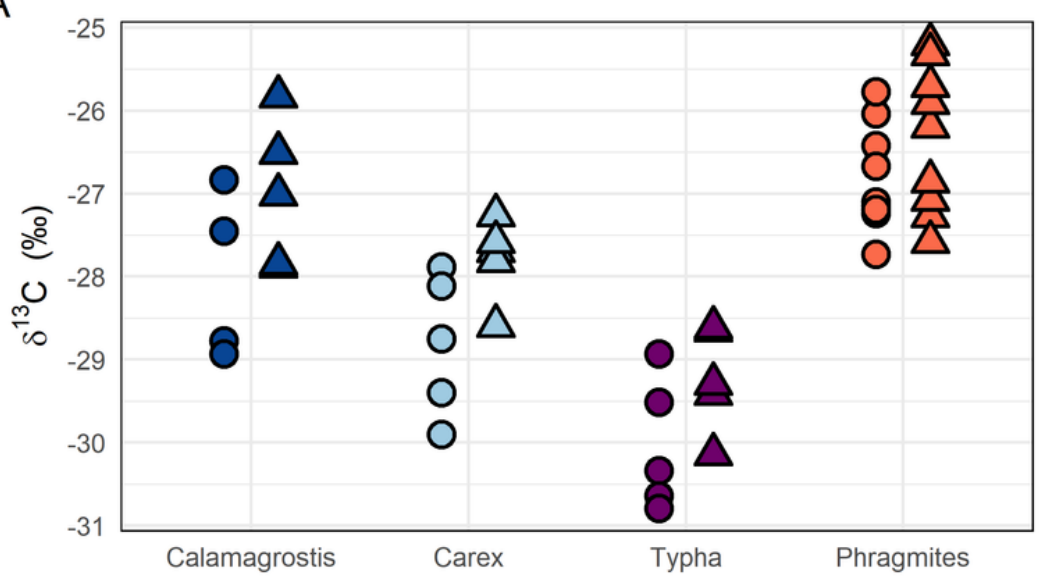

With competition
Without competition

B

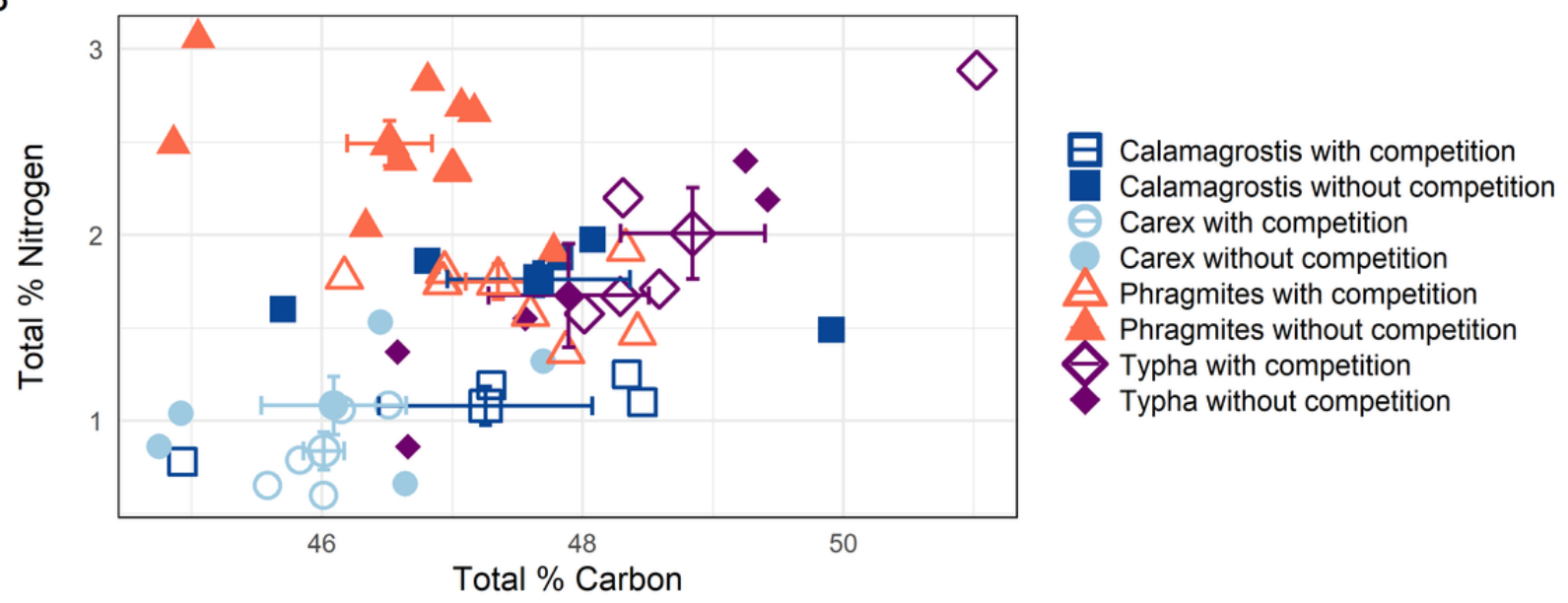

Figure 2

$\delta 13 \mathrm{C}$ values for each phytometer (A) and a scatter plot illustrating the carbon (\%) and nitrogen (\%) content in phytometer leaves (B). Large points with error bars represent the mean and standard error for each phytometer by treatment. 


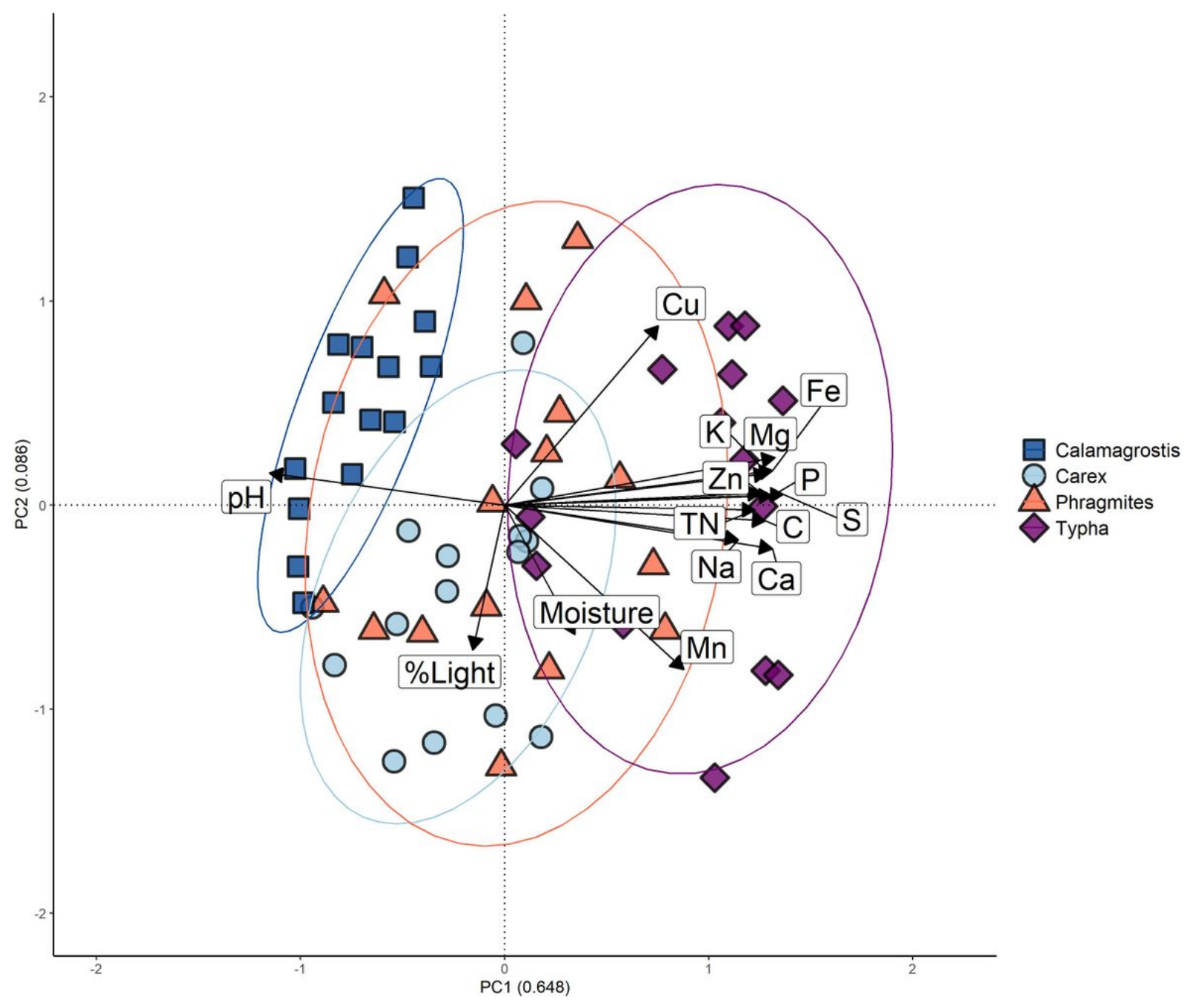

Figure 3

PCA using soil nutrients and percent incident light from marsh vegetation communities dominated by the target species: invasive P. australis, C. canadensis and C. aquatilis which represent remnant meadow marsh, and Typha spp. which represents remnant emergent marsh. The first two axes explain $75 \%$ of the variance in the data and were used to assess niche overlap among species. Ellipses are $90 \%$ confidence intervals for each group, and vectors represent all variables included in the PCA (Appendix I).

\section{Supplementary Files}

This is a list of supplementary files associated with this preprint. Click to download.

- AppendixRobichaudRooney2021.docx 